\title{
LAND SURFACE TEMPERATURE PROFILING AND ITS RELATIONSHIPS WITH LAND INDICES: A CASE STUDY ON LUCKNOW CITY
}

\author{
M. O. Sarif ${ }^{1, *}$, R. D. Gupta ${ }^{2}$ \\ ${ }^{1}$ Geographic Information System (GIS) Cell, Motilal Nehru National Institute of Technology Allahabad, \\ Prayagraj-211004, India - rgi1606@mnnit.ac.in / mdomarsarif@gmail.com \\ ${ }^{2}$ Civil Engineering Department and Member of GIS Cell, Motilal Nehru National Institute of Technology Allahabad, \\ Prayagraj-211004, India - rdg@mnnit.ac.in \\ Commission V, WG V/7 \& Commission IV, WG IV/6
}

KEY WORDS: LST, Land Indices, NDVI, NDBI, EBBI, Correlation Coefficients, LST profiling

\begin{abstract}
:
Globally, 54.5\% of the total population was living in urban settings in 2016 and a projection indicates that if the same trend goes, then this population will be $60 \%$ in 2030 . Natural land has been converted to impervious space rapidly which is altering the climate change. The main focus of the present paper is the study of Land Surface Temperature (LST) dynamics and its relationship with Land Indices, viz., Normal Difference Vegetation Index (NDVI) which is found negative, Normal Difference Built-up Index (NDBI) which is found positive, Enhanced Built-up and Bareness Index (EBBI) which is found positive in Lucknow city on both time points of 1993 and 2019. This study also includes the effects of land indices on LST profiling in nine different parts and eight different directions to explore the spatial dynamics of city landscape. The NDVI is found higher in the southern side than any other parts of the city in 2019 because of high vegetation growth which resulted in reduction of LST by $4.42{ }^{\circ} \mathrm{C}$ to $5.76{ }^{\circ} \mathrm{C}$ as compared to parts of the city. The results of NDBI and EBBI exhibit high built-up growth in the landscape of the Lucknow city especially from city center to $13 \mathrm{kms}$ (least growth in south-eastern side) from 1993 to 2019. The results indicate intensification of LST in the range of $0.26^{\circ} \mathrm{C}$ to $2.24^{\circ} \mathrm{C}$ between city centre and city periphery from 1993 to 2019 . The findings of the present study will help urban planners and policy makers to adopt suitable measures for sustainable planning for Lucknow city landscape to reduce the adverse effects of LST.
\end{abstract}

\section{INTRODUCTION}

Worldwide, $54.5 \%$ of total population lived in urban space in 2016 and projection said if the trend is same then it will be $60 \%$ in 2030 (UN, 2016). Between the pre-industrial period (18501900) and the recent post-industrial period (2006-2015), the global Land Surface Temperature (LST) has increased by 1.53 ${ }^{\circ} \mathrm{C}$ and global (ocean and land) mean surface air temperature increased by $0.87{ }^{\circ} \mathrm{C}$ (IPCC, 2019). The explosive nature of urbanisation rise has severe environmental consequences due to the effects of increased LST which has degrading impact on human health as well as climate change that is now one of the most concerned topics of the globe (Santos et al., 2017).

The surface features of city landscape constitute the diverse electromagnetic behaviour in respect to wide radiation, absorbance and evaporation where prevailing winds and long wave radiation result into augmented heat discharge (Bokaie et al., 2016). These surface properties constitute gravels, pebbles, asphalts and stones which hike the sensitivity and lower the evapotranspiration in the city space with significant effects on city environment (Babazadeh and Kumar, 2015; Son et al., 2017). This results into dramatic change in LST over city space where core city witness higher temperature than the rural/ suburban space. This difference pattern of LST, called Surface Urban Heat Island (SUHI), happens due to conversion of natural land surface into impervious surface and shrinking/ depletion of water bodies (Rousta et al., 2018).

* Corresponding author
At present, LST rise is one of crucial influencing factor for changing climate as well as quality of life for human (including animals) especially in a urban settings (Simwanda et al., 2019). The policy makers, urban planners, health authorities, urban investors and environmentalists are paying lot of attention to overcome its severe effects on various aspects of environment (Li et al., 2017). In recent past, researchers have carried out studies for the LST evaluation and its relationship with different land indices like Normal Difference Vegetation Index (NDVI), Normal Difference Built-up Index (NDBI) in different Indian cities including Delhi and Mumbai (Grover and Singh, 2015), Kolkata (Ghosh et al., 2018), Noida (Kikon et al., 2016), major cities of Punjab (Mukherjee et al., 2017), ten metropolitan cities of India (Sultana and Satyanarayana, 2018),

Singh et al. (2017) carried out analysis of spatial dynamics of Land Use/Land Cover (LU/LC), land indices and LST in Lucknow City where they explored the UHI for the years of 2000 and 2014. However, the quantitative analysis for the whole landscape was not carried out. (Singh et al., 2017)For Lucknow city, comparative analysis of thermal state and its effects due to land indices in different parts of the city and direction is lacking. There is a need to carry out study for quantitate analysis of intensity of land indices and LST in different direction of the city for depiction of the detailed status of the spatial pattern in city landscape.

The present study analyses the dynamics of spatial pattern of LST over the city landscape through direction wise spatial quantification. The role of land indices is also studied to find out the influence of NDVI, NDBI, and Enhanced Built-up and 
Bareness Index (EBBI) on the pattern of LST spatial dynamics on the city landscape.

Lucknow City is chosen as study area as it is capital of Uttar Pradesh State and is one of the fastest growing metropolitan economy and industrial development in North India. In this work, the correlation study of LST and land indices (NDVI, NDBI and EBBI) is carried out. For evaluating the effect of land indices on LST, dynamics profiling in eight different directions, namely, West, East, North, South, North-West, South-East, South-West, North-East, and one overall analysis from city center to city periphery is also carried out.

\section{MATERIAL AND METHODS}

\subsection{Study Area: Lucknow City, India}

Lucknow City, the capital of Uttar Pradesh, spread over 315.63 $\mathrm{km}^{2}$ and extending between longitude 80 $499^{\prime} 50^{\prime \prime} \mathrm{E}$ to $81^{\circ} 03^{\prime} 14 " \mathrm{E}$ and latitude $26^{\circ} 44^{\prime} 08^{\prime \prime} \mathrm{N}$ to $26^{\circ} 057^{\prime} 57^{\prime \prime} \mathrm{N}$ is selected as the study area (Figure 1). The Gomti River is flowing on central part of the city from North-West to South-East (Figure 1c). The city is located about $123.000 \mathrm{~m}$ above mean sea level (msl) and has sub-humid climate where minimum and maximum temperature range are $40-45^{\circ} \mathrm{C}$ and $5-15^{\circ} \mathrm{C}$ respectively with average rainfall of $904 \mathrm{~mm}$ (Singh et al., 2017).

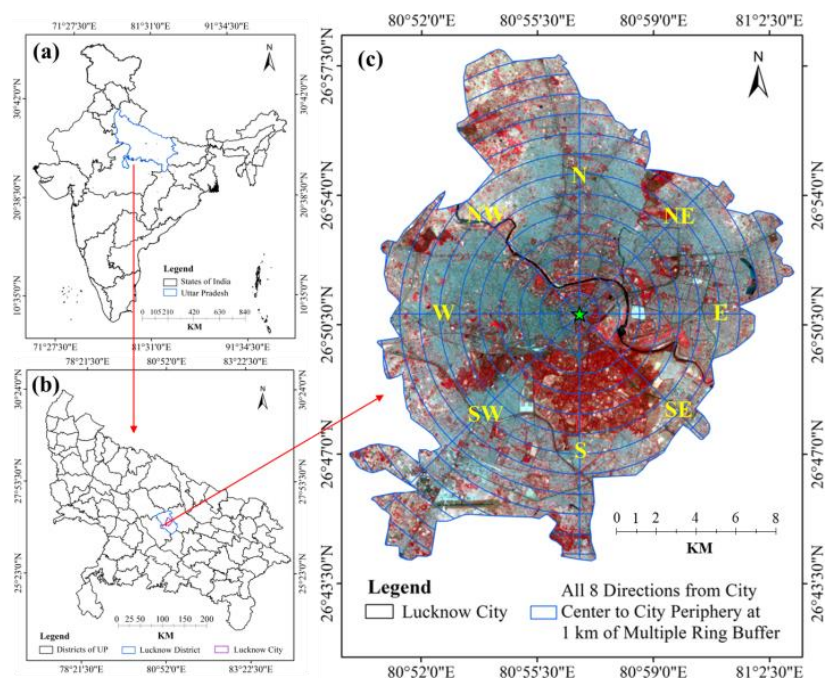

Figure 1. Study area, Lucknow City; (a) Location of Uttar Pradesh in India; (b) Location of Lucknow City in Uttar Pradesh; (c) Landsat 8 Standard False Colour Composite (FCC) of Lucknow City of 01/06/2019 with buffer zones and directions

\subsection{Satellite Images}

In this study, satellite images of Landsat Thematic Mapper (TM) of 09/06/1993, and Landsat Operational Land Imager (OLI)/ Thermal Infrared Scanner (TIRS) of 01/06/2019 (Table 1) are used which have spatial resolution of 30 meters (except Band 8 of Landsat OLI/TIRS). For the computation of land Indices (NDVI, NDBI and EBBI), bands 3-5 of Landsat TM, and bands 4-6 of Landsat OLI/TIRS are used. For computation of LST, band 6 of Landsat TM and Band 10 of Landsat OLI/TIRS are used. The satellite data is obtained from United States Geological Survey's portal (https://earthexplorer.usgs.gov/).

\begin{tabular}{|c|c|c|c|c|}
\hline \multirow{2}{*}{$\begin{array}{c}\text { Satellite } \\
\text { (Sensor) }\end{array}$} & \multirow{2}{*}{$\begin{array}{c}\text { Path/ } \\
\text { Row }\end{array}$} & \multirow{2}{*}{$\begin{array}{c}\text { Date \& } \\
\text { Time } \\
(\text { GMT) }\end{array}$} & \multicolumn{2}{|c|}{ LST Constant } \\
\cline { 4 - 5 } & & K1 & K2 \\
\hline $\begin{array}{c}\text { Landsat 5 } \\
\text { (TM) }\end{array}$ & $144 / 41$ & $\begin{array}{c}09 / 06 / 1993 \\
04: 29: 25\end{array}$ & $\begin{array}{c}607.76 \\
\text { (Band 6) }\end{array}$ & $\begin{array}{c}1260.56 \\
\text { (Band 6) }\end{array}$ \\
\hline $\begin{array}{c}\text { Landsat 8 } \\
\text { (OLI/TIRS) }\end{array}$ & $144 / 41$ & $\begin{array}{c}01 / 06 / 2019 \\
05: 06: 37\end{array}$ & $\begin{array}{c}774.8853 \\
\text { (Band 10) }\end{array}$ & $\begin{array}{c}1321.0789 \\
\text { (Band 10) }\end{array}$ \\
\hline
\end{tabular}

Table 1. Description of data used

\subsection{Retrieval of LST}

For extraction of LST, thermal band (band 6) of Landsat 5 and thermal band (band 10) of Landsat 8 are used to get spectral radiance using Equation (1) (Landsat 8 (L8) Data Users Handbook, 2016):

$L_{\alpha}=M_{L} * Q_{c a l}+A_{L}$

where, $L_{\alpha}=$ Top of Atmosphere (TOA) spectral radiance (watts/(m²*s*um)), $M_{L}=$ specific band's multiplicative rescaling factor from the metadata, $Q_{c a l}=$ quantized and calibrated Digital Number (DN) values of standard product, $A_{L}=$ specific band's additive rescaling factor from metadata.

Now, brightness temperature (at sensor) is calculated using Equation (2) (Rousta et al., 2018; Sultana and Satyanarayana, 2018):

$\Omega=\left[\frac{K_{2}}{\ln \left(\frac{K_{1}}{L_{\alpha}}+1\right)}\right]$

where, $\Omega=$ brightness temperature (at sensor), $K_{1}$ and $K_{2}=$ constants for thermal conversion from metadata (Table 1).

Then, LST (in K) is derived by brightness temperature and correction of emissivity using Equation (3):

$$
\Phi=\left[\frac{\Omega}{1+w\left(\frac{\Omega}{p}\right) \ln (e)}\right]
$$

Where, $\Phi=$ temperature (at sensor), $w=$ emitted radiance wavelength (11.5 $\mu \mathrm{m}$ for Band 6 of Landsat $5 \mathrm{TM}$, and 10.8 $\mu m$ for Band 10 of Landsat 8 OLI/TIRS), $p=h \times c / s$ ( $\left.1.438 \times 10^{-2} \mathrm{mK}\right), h=$ plank's constant $\left(6.626 \times 10^{-34} \mathrm{Js}\right), s=$ Boltzmann Constant $\left(1.38 \times 10^{-23} \mathrm{~J} / \mathrm{K}\right), c=$ velocity of light ( $\left.2.988 \times 10^{8} \mathrm{~m} / \mathrm{s}\right)$.

Land surface emissivity $(e)$ is obtained using Equation (4): $e=n P_{v}+m$ 
where, $n=0.004$ (Estoque and Murayama, 2017), $m=0.986$ (Estoque and Murayama, 2017).

Proportion of vegetation $\left(P_{v}\right)$ is measured using Equation (5):

$P_{v}=\left[\frac{N D V I-N D V I_{\text {minimum }}}{N D V I_{\text {maximum }}-N D V I_{\text {minimum }}}\right]$

Where, NDVI is computed using Equation (6) in section 2.4.

\subsection{NDVI Computation}

NDVI is one of the important indicators of urban climate. It is calculated using Equation (6):

$\mathrm{NDVI}=\left[\frac{\mathrm{NIR}_{\text {Band }}-\operatorname{Red}_{\text {Band }}}{\mathrm{NIR}_{\text {Band }}+\operatorname{Red}_{\text {Band }}}\right]$

Where, in Landsat $5 \mathrm{TM}, \mathrm{NIR}_{\text {Band }}$ is band 4 and $\operatorname{Red}_{\text {Band }}$ is band 3; and in Landsat 8 OLI/TIRS, NIR Band $_{1}$ is band 5 and $\operatorname{Red}_{\text {Band }}$ is band 4.

It ranges between -1 to +1 . Its large positive values is vegetation, lower positive values built-up area or bare soils, the negative values is water bodies (Rousta et al., 2018). It exhibits the amount vegetation, phenology, and health information (Pal and Ziaul, 2017).

\subsection{NDBI Computation}

NDBI is another important indicator of urban climate. It is calculated using Equation (7):

$\mathrm{NDBI}=\left[\frac{\mathrm{MIR}_{\text {Band }}-\mathrm{NIR}_{\text {Band }}}{\mathrm{MIR}_{\text {Band }}+\mathrm{NIR}_{\text {Band }}}\right]$

Where, in Landsat $5 \mathrm{TM}, \mathrm{MIR}_{\mathrm{Band}}$ is band 5 and $\mathrm{NIR}_{\text {Band }}$ is band 4; and in Landsat 8 OLI/TIRS, MIR ${ }_{\text {Band }}$ is band 6 and $\mathrm{NIR}_{\text {Band }}$ is band 5 .

It ranges between -1 to +1 . Its higher positive values is bare soils, lower positive values and lower negative (adjacent to 0 ) is built-up area, its large negative values is indicating water, vegetation, (Rousta et al., 2018).

\subsection{EBBI Computation}

EBBI is another one of the important indicators of urban climate. It is calculated using Equation (8):

$\mathrm{EBBI}=\left[\frac{\mathrm{MIR}_{\text {Band }}-\mathrm{NIR}_{\text {Band }}}{10 \sqrt{\mathrm{MIR}_{\text {Band }}+\mathrm{TIR}_{\text {Band }}}}\right]$

Where, in Landsat $5 \mathrm{TM}, \mathrm{MIR}_{\text {Band }}$ is band $5, \mathrm{NIR}_{\text {Band }}$ is band 4 and TIR $_{\text {Band }}$ is band 6; and in Landsat 8 OLI/TIRS, MIR Band $_{\text {is }}$ band 6, NIR ${ }_{\text {Band }}$ is band 5 and $\operatorname{TIR}_{\text {Band }}$ is band 10 .

It ranges between 0 to +1 . Its higher values $(>0.35)$ indicate bare land and lower values indicate built-up area (0.1-0.35) (Assyakur et al., 2012).

\subsection{Statistical Analysis}

To extract the effect of land indices (NDVI, NDBI and EBBI) distinctly on LST intensification, scatter plots are made for both time points of 1993 and 2019 using linear regression. Pearson's correlation coefficients (r) is used to evaluate the relationship among LST vs NDVI, LST vs NDBI, and LST vs EBBI, where LST is dependent variable and NDVI/ NDBI/ EBBI are independent variables. Pearson's ' $r$ ' is derived using Equation (9):

$$
r=\frac{\sum_{i}^{n}\left(x_{i}-\bar{x}\right)\left(y_{i}-\bar{y}\right)}{\sqrt{\sum_{i=1}^{n}\left(x_{i}-\bar{x}\right)^{2}} \sqrt{\sum_{i=1}^{n}\left(y_{i}-\bar{y}\right)^{2}}}
$$

Where, $x_{i}$ defines NDVI/ NDBI/ EBBI values, $y_{i}$ defines LST values.

\subsection{Urban-Rural Gradient}

The urban-rural gradient approach is used to evaluate the difference of spatial pattern of land indices (NDVI, NDBI and EBBI) on LST. This approach is used to extract dynamics of LST, NDVI, NDBI and EBBI at $1 \mathrm{~km}$ of intervals from city center to city periphery up to $16 \mathrm{~km}$ in eight different directions, viz, West (up to $16 \mathrm{~km}$ ), East (up to $13 \mathrm{~km}$ ), North (up to $14 \mathrm{~km}$ ), South (up to $16 \mathrm{~km}$ ), North-West (up to $16 \mathrm{~km}$ ), South-East (up to $13 \mathrm{~km}$ ), South-West (up to $16 \mathrm{~km}$ ), and North-East (up to $12 \mathrm{~km}$ ), and an overall analysis from city center to city periphery (Figure 1c).

\section{RESULTS AND DISCUSSION}

\subsection{Relationship of Land Indices (NDVI/ NDBI/ EBBI) and LST}

The spatio-temporal distribution of LST, NDVI, NDBI and EBBI of 1993 and 2019 for Lucknow City is shown in Figure 2. The statistics of LST and land indices (NDVI, NDBI and EBBI) with their correlation coefficients are compiled in Table 2. It can be observed that the computed mean LST was $31.572{ }^{\circ} \mathrm{C}$ in 1993 which increased to $31.915^{\circ} \mathrm{C}$ in 2019 . The computed mean NDVI was 0.165 in 1993 which increased to 0.215 in 2019. The computed mean NDBI in 1993 was 0.031 which decreased to -0.024 in 2019. The mean EBBI found in 1993 was 0.234 which decreased to 0.222 in 2019 .

The pattern of NDBI (Figure 1c and 1g) and EBBI (Figure 1d and $1 \mathrm{~h}$ ) clearly shows that built-up land has explosively increased at the cost of other natural land like vegetation, water, and bare soils from 1993 to 2019. NDVI includes forest lands, grass lands and crops lands. The pattern of NDVI shows increasing trend from 1993 (Figure 1b) to 2019 (Figure 1f). It can be observed that LST (Figure 1a and Figure 1e) has increased from 1993 to 2019.

The relationship of Land Indices (NDVI/ NDBI/ EBBI) and LST for Lucknow City for 1993 and 2019 is shown in Figure 3. The relationship between NDVI and LST is negative both the time points, and correlation coefficient was $-0.396(p<0.001)$ in 1993 (Figure 3a) which increased to $-0.363(p<0.001)$ in 2019 (Figure 3d) (Table 2). This means vegetation played important role to reduce the intensity of LST over the landscape of the city. The relationship between NDBI and LST is positive at both time points with correlation coefficients being 0.648 ( $p$ $<0.001$ ) in 1993 (Figure 3b) which increased to 0.681 ( $p<$ 
0.001) in 2019 (Figure 3e). This means built-up land played important role for escalating the intensity of LST over the landscape of the city. The relationship between EBBI and LST is positive both the times where correlation coefficients was $0.643(p<0.001)$ in 1993 (Figure 3c) which decreased to 0.628 $(p<0.001)$ in 2019 (Figure 3f). This means built-up land and bare land together played crucial role in escalation of the intensity of LST over the landscape of the city.
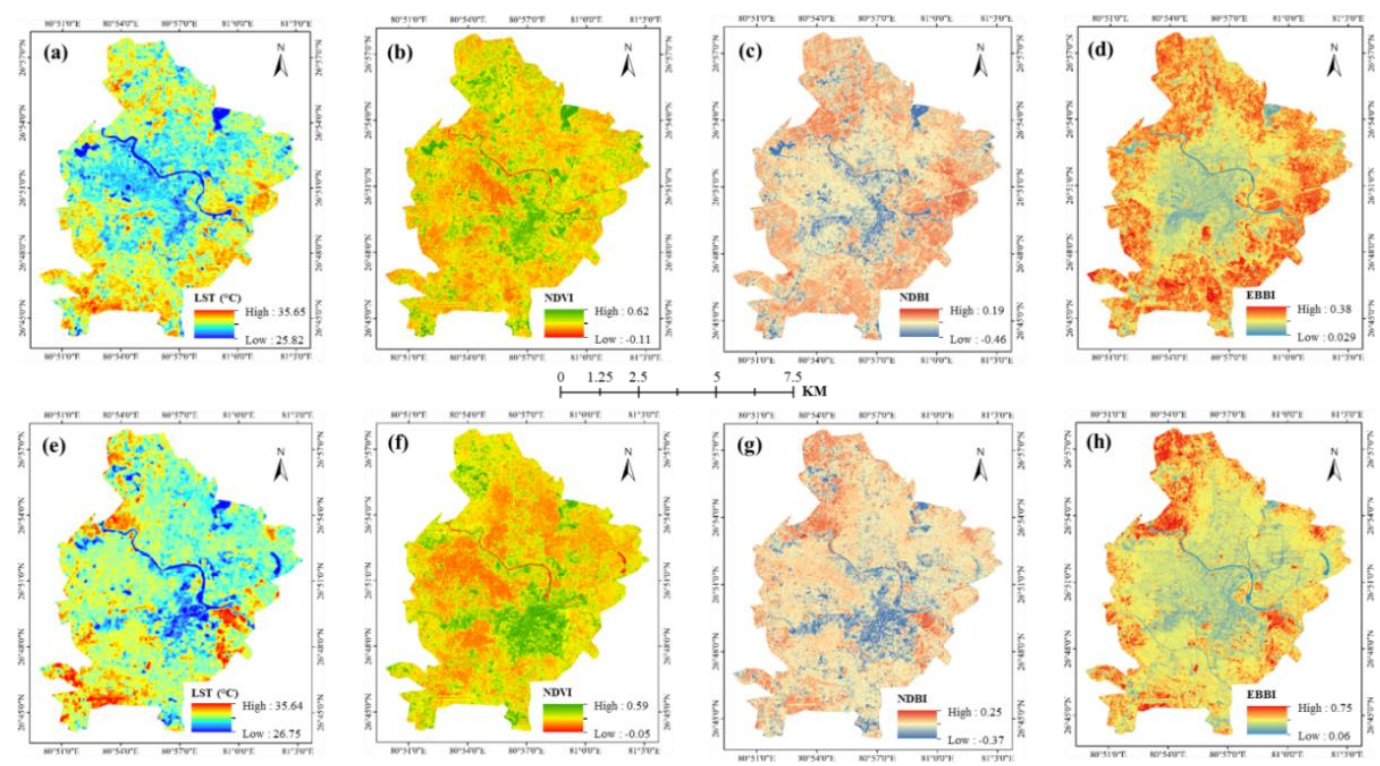

Figure 2. Spatial dynamics of LST and Land Indices (NDVI, NDBI and EBBI) on the Landscape of Lucknow City: (a d) spatial distribution of LST, NDVI, NDBI, and EBBI respectively of 09/06/1993; (e - f) spatial distribution of LST, NDVI, NDBI and EBBI respectively

\begin{tabular}{|c|c|c|c|c|c|c|c|}
\hline & \multicolumn{5}{|c|}{$\begin{array}{l}\text { Statistics of LST and Land Indices } \\
\text { (NDVI, NDBI and EBBI) }\end{array}$} & \multicolumn{2}{|c|}{$\begin{array}{l}\text { Relationship among Land } \\
\text { Indices and LST }\end{array}$} \\
\hline Date & Variables & Minimum & Maximum & Mean & $\begin{array}{l}\text { Standard } \\
\text { Deviation }\end{array}$ & $\begin{array}{l}\text { Correlation } \\
\text { with LST } \\
\text { (r) }\end{array}$ & $\begin{array}{c}\text { Significance } \\
(P)\end{array}$ \\
\hline \multirow{4}{*}{ 09/06/1993 } & LST & 25.823 & 35.647 & 31.572 & 1.114 & - & - \\
\hline & NDVI & -0.113 & 0.617 & 0.165 & 0.078 & -0.396 & $<0.001$ \\
\hline & NDBI & -0.464 & 0.187 & 0.031 & 0.07 & 0.648 & $<0.001$ \\
\hline & EBBI & 0.029 & 0.384 & 0.234 & 0.05 & 0.643 & $<0.001$ \\
\hline \multirow{4}{*}{ 01/06/2019 } & LST & 26.75 & 35.638 & 31.915 & 0.929 & - & - \\
\hline & NDVI & -0.051 & 0.585 & 0.215 & 0.078 & -0.363 & $<0.001$ \\
\hline & NDBI & -0.374 & 0.252 & -0.024 & 0.063 & 0.681 & $<0.001$ \\
\hline & EBBI & 0.06 & 0.749 & 0.222 & 0.04 & 0.628 & $<0.001$ \\
\hline
\end{tabular}

Table 2. Statistics of LST and Land Indices (NDVI, NDBI, and EBBI) with their correlation coefficients
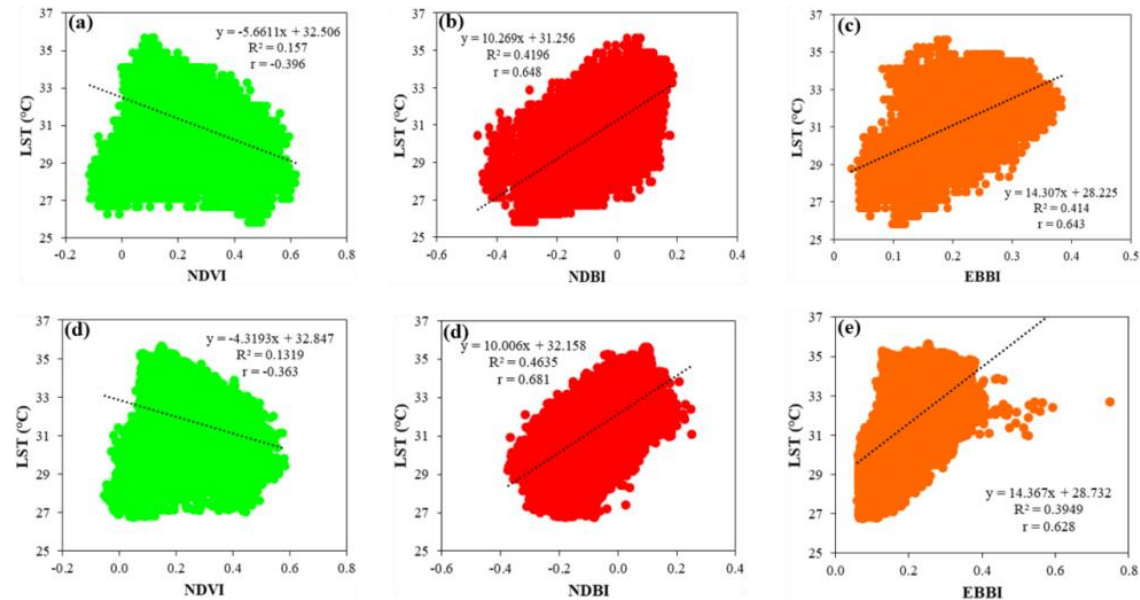

Figure 3. Scatter plots of LST and Land Indices for 09/06/1993: (a) LST vs NDVI, (b) LST vs NDBI, (c) LST vs EBBI; for 01/06/2019: (d) LST vs NDVI, (e) LST vs NDBI, (f) LST vs EBBI 


\subsection{Effects of Land Indices (NDVI/ NDBI/ EBBI) on LST Profiling}

The dynamics of spatio-temporal pattern of LST, NDVI, NDBI and EBBI of 1993 and 2019 in eight directions, viz, West, East, North, South, North-West, South-East, South-West, North-East, and an overall analysis from city center to city periphery for Lucknow city is shown in Figure 4.

\section{West to East direction:}

In west (from city center towards city periphery), the LST has observed $30.51{ }^{\circ} \mathrm{C}$ to $32.37{ }^{\circ} \mathrm{C}$ in 1993 and which has been increased to $31.52{ }^{\circ} \mathrm{C}$ to $32.60{ }^{\circ} \mathrm{C}$ in 2019 ; whereas NDVI has observed 0.038 to 0.271 in 1993 and which has been increased to 0.093 to 0.255 in 2019 (except at $16 \mathrm{~km}$ ); where NDBI has observed -0.074 to 0.054 in 1993 and which has been increased to -0.067 to 0.005 in 2019 ; and EBBI has observed 0.124 to 0.261 in 1993 and which has been decreased to 0.138 to 0.264 in 2019 (Figure 4a).

In East (from city center towards city periphery), the LST has observed $30.17{ }^{\circ} \mathrm{C}$ to $32.05{ }^{\circ} \mathrm{C}$ in 1993 and which has been increased to $30.87{ }^{\circ} \mathrm{C}$ to $32.54{ }^{\circ} \mathrm{C}$ in 2019 ; whereas NDVI has observed 0.038 to 0.219 in 1993 and which has been increased to 0.093 to 0.275 in 2019 (except at $16 \mathrm{~km}$ ); where NDBI has observed -0.046 to -0.059 in 1993 and which has been increased to -0.081 to 0.0002 in 2019 ; and EBBI has observed 0.124 to 0.263 in 1993 and which has been decreased to 0.139 to 0.250 in 2019 (Figure 4a)

Between West and East direction (Figure 4a-d), mean LST was higher in West than East in the variation of $0.32^{\circ} \mathrm{C}$ to $2.20^{\circ} \mathrm{C}$ in 1993 and again it was higher in West than East in 2019 by the variation of $0.06{ }^{\circ} \mathrm{C}$ to $1.73{ }^{\circ} \mathrm{C}$ (Figure 4a); whereas, NDVI mean has found lower in West than East by the variation of 0.01 to 0.181 in 1993 and it was in 2019 where West again lower than East in the variation of 0.052 to 0.182 (except higher peak in west near $15-16 \mathrm{~km}$ towards west) (Figure $4 \mathrm{~b}$ ); where, NDBI mean has found higher in West than East by the variation of -0.010 to 0.113 in 1993 and it was in 2019 where West again higher than East in the variation of 0.005 to 0.086 (Figure 4c); and EBBI mean has found also higher in West than East by the variation of 0.003 to 0.137 in 1993 (except higher peak in west at $8 \mathrm{~km}$ towards east from City center) and it was in 2019 where West again higher than East in the variation of 0.014 to 0.125 (Figure 4d). Here, it has clear that western part of city has more urbanisation than eastern part.

The above two direction (West and East) has been used to extract the difference of change dynamics between West and East in 1993 and 2019. This similar approach has been employed to get the difference of change dynamics between rests of the directions, like as, North and South, North-West and South-East, South-West and North-East.

\section{North to South direction:}

Between North and South direction (Figure 4e-f), LST mean was higher in North than South in the variation of $0.34{ }^{\circ} \mathrm{C}$ to $1.88^{\circ} \mathrm{C}$ in 1993 and again it was higher in North than South in 2019 by the drastic variation of $4.42^{\circ} \mathrm{C}$ to $5.76{ }^{\circ} \mathrm{C}$ (Figure 4e). Where, NDVI mean has found lower in North than South by the variation of 0.02 to 0.05 in 1993 and it was in 2019 where North again lower than South in the variation of 0.02 to 0.15 (Figure 4f). Where, NDBI was higher in North than South in the variation of -0.001 to 0.02 in 1993 and it was in 2019 where North again higher than South in the variation of 0.003 to -0.04 (Figure 4g). EBBI mean has found also higher in North than South by the variation of 0.02 to 0.04 in 1993 (except higher peak in west near 7-10 km towards South from City center) and it was in 2019 where North again higher than South in the variation of 0.02 to 0.09 (Figure $4 \mathrm{~h}$ ). Here, it has found drastic effects of urban development in northern side of the city whereas in southern side has found rapid higher vegetation growth in 2019. This growth of vegetation in south direction (Figure $5 \mathrm{c}$ and $5 \mathrm{e}$ ) and its effects on LST in same direction (Figure $5 \mathrm{a}$ and $5 \mathrm{~b}$ ) has been validated by Landsat OLI/TIRS of 01/06/2019 (FCC image) (Figure 5d) and Google Earth image of 09/05/2019 (Figure 5f)

\section{North-West to South-East direction:}

Between North-West and South-East direction (Figure 4i-1), LST mean was higher in North-West than South-East in the variation of $0.36^{\circ} \mathrm{C}$ to $2.1^{\circ} \mathrm{C}$ in 1993 and again it was higher in North-West than South-East in 2019 by the drastic variation of $1{ }^{\circ} \mathrm{C}$ to $2.17^{\circ} \mathrm{C}$ (Figure $4 \mathrm{i}$ ). Where, NDVI mean has found lower in North-West than South-East by the variation of 0.05 to 0.21 in 1993 and it was in 2019 where North-West again lower than South-East in the variation of 0.09 to 0.24 (Figure 4j). Where, NDBI was higher in North-West than South-East in the variation of -0.02 to 0.12 in 1993 (except higher peak in near 8$10 \mathrm{~km}$ towards South-East from City center) and it was in 2019 where North-West again higher than South-East in the variation of 0.02 to 0.14 (Figure 4k). EBBI mean has found also higher in North-West than South-East by the variation of 0.02 to 0.17 in 1993 (except higher peak in west near 8-10 km towards SouthEast from City center) and it was in 2019 where North-West again higher than South-East in the variation of 0.02 to 0.2 (Figure 41). Here, it has also found drastic effects of urban development in north-western side of the city whereas in southeastern side has found most vegetation growth (especially from $1 \mathrm{kms}$ to $7 \mathrm{kms}$ ) in 2019.

\section{South-West to North-East direction:}

Between South-West and North-East direction (Figure 4m-p), LST mean was higher in South-West than North-East in the variation of $0.72{ }^{\circ} \mathrm{C}$ to $2.37{ }^{\circ} \mathrm{C}$ in 1993 and again it was higher in South-West than North-East in 2019 by the variation of 0.52 ${ }^{\circ} \mathrm{C}$ to $2.03{ }^{\circ} \mathrm{C}$ (Figure $4 \mathrm{~m}$ ). Where, NDVI mean has found higher in South-West than North-East by the variation of 0.04 to 0.23 in 1993 and it was in 2019 where South-West again higher than North-East in the variation of 0.003 to 0.18 (Figure $4 n$ ). Where, NDBI was higher in South-West than North-East in the variation of 0.01 to 0.09 in 1993 and it was in 2019 where South-West again higher than North-East in the variation of 0.001 to 0.06 (except higher peak in near $10-12 \mathrm{~km}$ towards North-East from City center) (Figure 4o). EBBI mean has found also higher in South-West than North-East by the variation of 0.01 to 0.07 in 1993 (except higher peak in west near $10-12 \mathrm{~km}$ towards North-East from City center) and it was in 2019 where South-West again higher than North-East in the variation of 0.01 to 0.06 (Figure 4p). Here, it has also found drastic effects of urban development in both south-western side as well as north-eastern side of the city but south-western side was having more intense urban development with bare land effects in 2019. 


\section{City Center to City Periphery:}

Between city center and city periphery (Figure 4q-t), LST has found $0.26^{\circ} \mathrm{C}$ to $2.24{ }^{\circ} \mathrm{C}$ of higher variation from 1993 to 2019 (Figure 4q). Where, NDVI has found higher variation between city center and city periphery from 1993 to 2019 by 0.05 to 0.22 (except higher peak in near $16 \mathrm{~km}$ towards City periphery from City center) (Figure 4r). NDBI has found lower variation between city center and city periphery from 1993 to 2019 by in the range of -0.05 to 0.08 (except slight higher in near $16 \mathrm{~km}$ towards City periphery from City center) (Figure 4s). EBBI has found higher variation in city center to city periphery from 1993 to 2019 by in the range of 0.01 to 0.13 (except higher peak in near 7-11 km towards City periphery from City center) (Figure $4 \mathrm{t})$. Here, it has found the drastic effects of urban development from $4 \mathrm{kms}$ from city center to $14 \mathrm{kms}$ of city center in 2019.
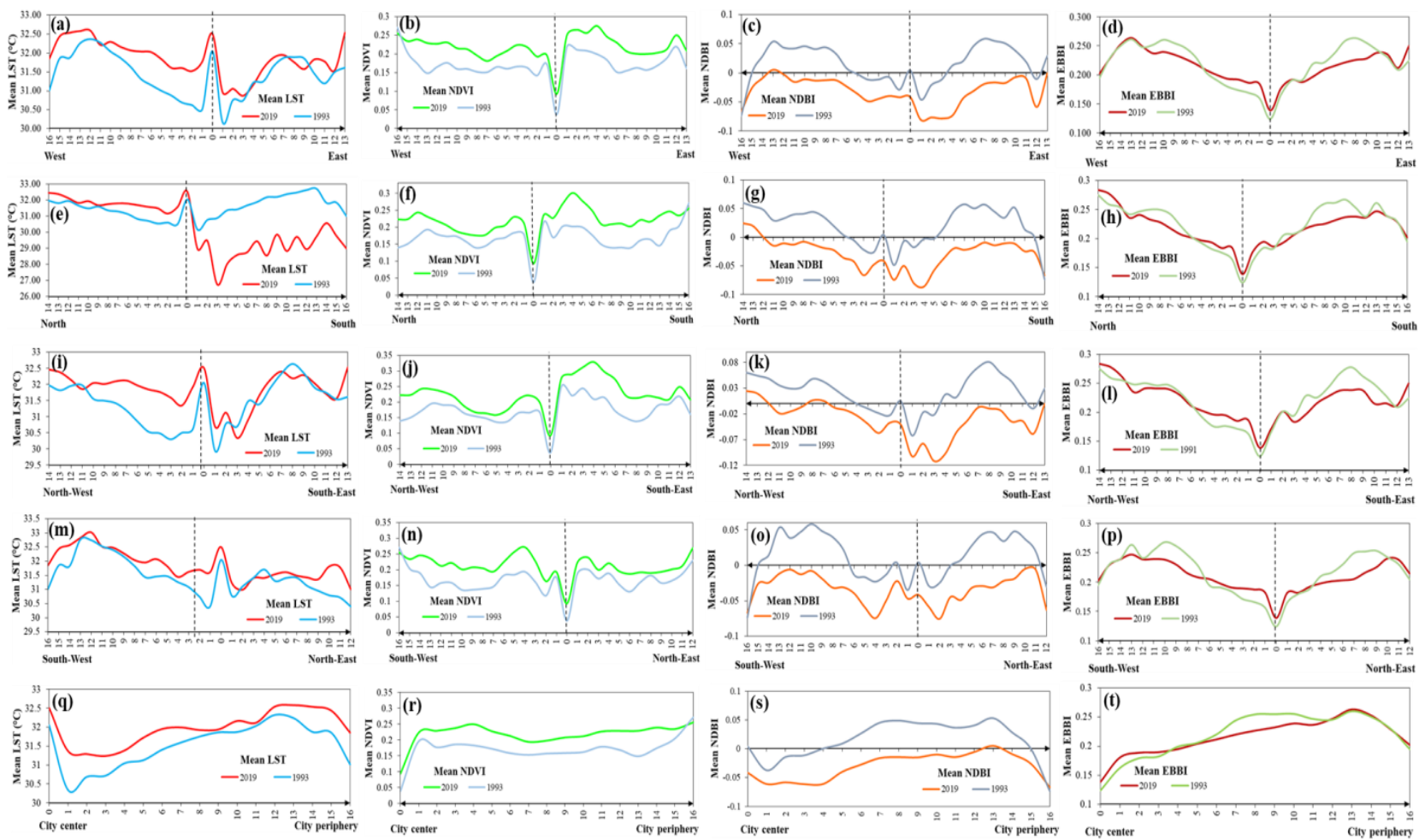

Figure 4. Spatial dynamics of LST and Land Indices: (a - d) Pattern of LST, NDVI, NDBI and EBBI in 1993 and 2019 in West to

East direction respectively; (e - h) Pattern of LST, NDVI, NDBI and EBBI in 1993 and 2019 in North to South direction respectively; (i - 1) Pattern of LST, NDVI, NDBI and EBBI in 1993 and 2019 in North-West to South-East direction respectively;

(m - p) Pattern of LST, NDVI, NDBI and EBBI in 1993 and 2019 in South-West to North-East direction respectively; (q - t) Pattern of LST, NDVI, NDBI and EBBI in 1993 and 2019 on over all analysis from City centre to City periphery respectively

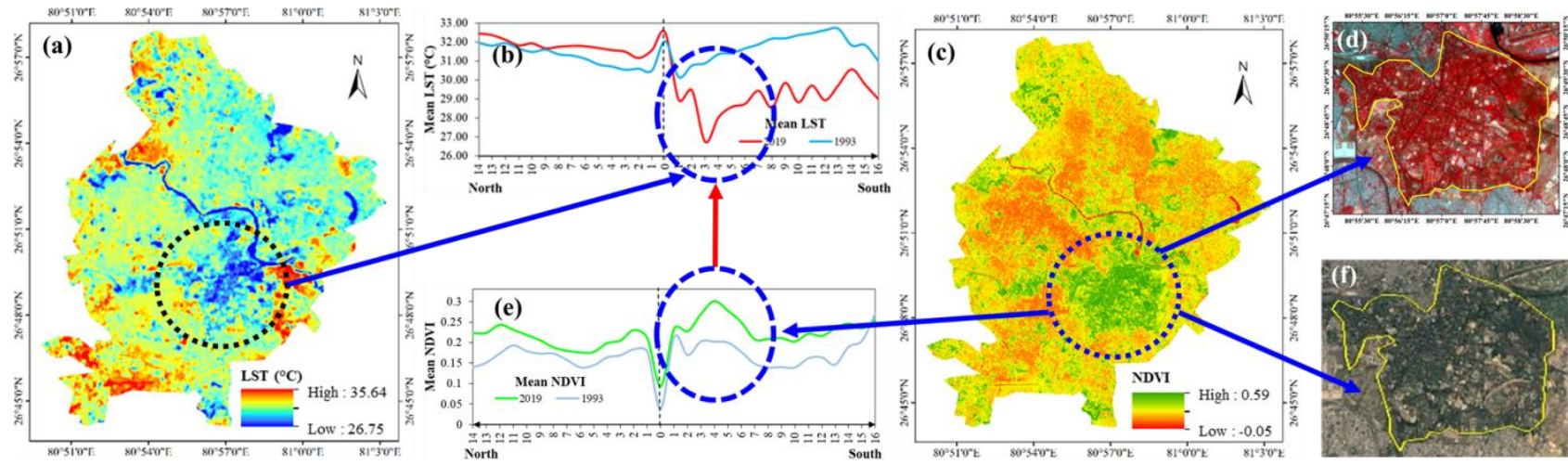

Figure 5. Validation of vegetation growth in south-east direction and its effect on LST in same direction using Landsat image and Google Earth Image: (a) LST in time-point of 01/06/2019; (b) LST distributional profile on south-east direction in time-point of 01/06/2019; (c) NDVI in time-point of 01/06/2019; (d) NDVI distributional profile on south-east direction in time-point of 01/06/2019; (e) NDVI distributional profile on south-east direction in time-point of 01/06/2019; (e) Selected circle portion on Landsat OLI/TIRS image in time-point of 01/062019; (f) Selected circle portion on Google Earth image in time-point of 09/05/2019 respectively 


\subsection{Study of Thermal State and Land Indices in Urban Planning}

The study of LST and land indices (NDVI, NDBI and EBBI) for Lucknow city has significant importance to get the spatial dynamics of the city landscape in terms of natural space diversities and thermal state along different directions of the city.

The results of NDBI and EBBI exhibits overall huge built-up growth in the landscape of Lucknow City from city center to 13 kms (least growth in south-eastern side) from 1993 to 2019. The high NDVI is found in the southern side due to the huge vegetation growth which resulted in the reduction of LST by $4.42{ }^{\circ} \mathrm{C}$ to $5.76{ }^{\circ} \mathrm{C}$ as compared to northern parts of the city in 2019 (Figure 4e). This clearly explains that vegetation has prominent role to reduce the LST. This also explains that northern part has been explosively developed into urban settings that southern part during 1993-2019.

Our results found that LST has intensified throughout from city center to city periphery from 1993 to 2019 in the range of $0.26^{\circ} \mathrm{C}$ to $2.24^{\circ} \mathrm{C}$ (Figure 4). This finding has crucial implication on the city climate. The information derived from the present study regarding LST dynamics of the city will provide a useful insight to urban planners and policy makers in adopting sustainable planning for city landscape by reducing the severe effects of LST.

Presently, people from different part of world are using numerous mitigation strategies, such as growing plants on roofs (green roofs), tree plantation on streets, cool roof creation, use of light materials and paints (Mohajerani et al., 2017). Other strategies include improved wind flow system by designing the size, shape and orientation of the structure of the building (Sen et al., 2019). Other than this, novel mitigation approaches like creation of numerous small to large scale water bodies, plantation of trees and grasses on barren space, use of water harvesting can be noteworthy to enhance the local ecosystem of city landscape (Estoque et al., 2012; Ranagalage et al., 2018; Santos et al., 2017). In this above mitigation strategies making, the monitoring of spatiotemporal remote sensing datasets has been playing significant role to understand the real scenario of the landscape (Sarif et al., 2017). Along with this, public awareness regarding contribution towards reducing LST intensification is essential to create a systematic approach for implementation of plans and policies to improve the city environment.

\section{CONCLUSION}

The result of relationship between LST vs. NDVI is found negative, LST vs. NDBI is found positive, and LST vs. EBBI is found positive in both time points of 1993 and 2019. This relationship pattern describes that built-up area plays a significant role in enhancing the LST at greater extent by $2^{\circ} \mathrm{C}$ to $4^{\circ} \mathrm{C}$. On the other hand, vegetation also has important role in reducing the LST distribution at large extent by $2^{\circ} \mathrm{C}$ to $6^{\circ} \mathrm{C}$.

The cooler most parts of the city were South and South-East as these parts of Lucknow City have high vegetation growth in 2019. On the other hand, the hotter most parts of the city were South-West and North-West in 2019. The major built-up developed parts were North-West, South-West and North-East.

The overall change of LST observed is in the range of $0.26^{\circ} \mathrm{C}$ to $2.24^{\circ} \mathrm{C}$ from city center to city periphery where specifically within $1 \mathrm{~km}$ to $13 \mathrm{~km}$, a huge built-up development has taken place from 1993 to 2019. The lesser built-up development is in South-East.

On the basis of our findings, it can be said that aforesaid mitigation plans and policies (section 3.3) need to be incorporated in Lucknow City to reduce the severe effects of LST intensification and for the sustainability of the city climate as well as for making the living standard of human life better. This can help in reducing the LST intensification in climate change.

\section{ACKNOWLEDGEMENTS}

Authors are thankful to USGS for making Landsat TM and Landsat OLI/TIRS data available on their portal free. Author, Md. Omar Sarif, is also grateful to University Grants Commission (UGC) for provided him financial support through Maulana Azad National Fellowship (MANF) scheme (2017-18).

\section{REFERENCES}

As-syakur, A.R., Adnyana, I.W.S., Arthana, I.W., Nuarsa, I.W., 2012. Enhanced Built-Up and Bareness Index ( EBBI ) for Mapping Built-Up and Bare Land in an Urban Area. Remote Sens. 4, 2957-2970. https://doi.org/10.3390/rs4102957

Babazadeh, M., Kumar, P., 2015. Estimation of the urban heat island in local climate change and vulnerability assessment for air quality in Delhi. Eur. Sci. J. 1, 55-65.

Bokaie, M., Zarkesh, M.K., Arasteh, P.D., Hosseini, A., 2016. Assessment of urban heat island based on the relationship between land surface temperature and land use/land cover in Tehran. Sustain. Cities Soc. 23, 94-104. https://doi.org/http://dx.doi.org/10.1016/j.scs.2016.03.009

Estoque, R.C., Estoque, R.S., Murayama, Y., 2012. Prioritizing Areas for Rehabilitation by Monitoring Change in BarangayBased Vegetation Cover 46-68. https://doi.org/10.3390/ijgi1010046

Estoque, R.C., Murayama, Y., 2017. Monitoring surface urban heat island formation in a tropical mountain city using Landsat data ( 1987 - 2015 ). ISPRS J. Photogramm. Remote Sens. 133, $18-29$.

https://doi.org/https://doi.org/10.1016/j.isprsjprs.2017.09.008

Ghosh, S., Chatterjee, N. Das, Santanu, C., 2018. Relation between urban biophysical composition and dynamics of land surface temperature in the Kolkata metropolitan area : a GIS and statistical based analysis for sustainable planning. Model. Earth Syst. Environ. https://doi.org/10.1007/s40808-018-0535-9 Grover, A., Singh, R.B., 2015. Analysis of urban heat island (UHI) in relation to normalized difference vegetation index (NDVI): A comparative study of Delhi and Mumbai. Environments 2, 125-138. https://doi.org/10.3390/environments2020125

IPCC, 2019. Climate Change and Land. An IPCC Special Report on climate change, desertification, land degradation, sustainable land management, food security, and greenhouse gas fluxes in terrestrial ecosystems. Summary for Policymakers., Intergovernmental Panel on Climate Change (IPCC,2019). https://doi.org/10.4337/9781784710644 
Kikon, N., Singh, P., Singh, S.K., Vyas, A., 2016. Assessment of urban heat islands (UHI) of Noida City, India using multitemporal satellite data. Sustain. Cities Soc. 22, 19-28. https://doi.org/10.1016/j.scs.2016.01.005

Landsat 8 (L8) Data Users Handbook, Version 2. ed, 2016. , Department of the Interior U.S. Geological Survey. United States Geological Survey, Sioux Falls, South Dakota.

Li, X., Zhou, Y., Asrar, G.R., Imhoff, M., Li, X., 2017. The surface urban heat island response to urban expansion : A panel analysis for the conterminous United States. Sci. Total Environ. 605-606, https://doi.org/10.1016/j.scitotenv.2017.06.229

Mohajerani, A., Bakaric, J., Jeffrey-Bailey, T., 2017. The urban heat island effect, its causes, and mitigation, with reference to the thermal properties of asphalt concrete. J. Environ. Manage. 197, 522-538. https://doi.org/10.1016/j.jenvman.2017.03.095

Mukherjee, S., Joshi, P.K., Garg, R.D., 2017. Analysis of urban built-up areas and surface urban heat island using downscaled MODIS derived land surface temperature data. Geocarto Int. 32, 900-918. https://doi.org/10.1080/10106049.2016.1222634

Pal, S., Ziaul, S., 2017. The Egyptian Journal of Remote Sensing and Space Sciences Detection of land use and land cover change and land surface temperature in English Bazar urban centre q. Egypt. J. Remote Sens. Sp. Sci. 20, 125-145. https://doi.org/10.1016/j.ejrs.2016.11.003

Ranagalage, M., Dissanayake, D., Murayama, Y., Zhang, X., Estoque, R.C., Perera, E., Morimoto, T., 2018. Quantifying Surface Urban Heat Island Formation in the World Heritage Tropical Mountain City of Sri Lanka. ISPRS Int. J. GeoInformation 7, 1-18. https://doi.org/10.3390/ijgi7090341

Rousta, I., Sarif, M.O., Gupta, R.D., Olafsson, H., Ranagalage, M., Murayama, Y., Zhang, H., Mushore, T., 2018. Spatiotemporal Analysis of Land Use/Land Cover and Its Effects on Surface Urban Heat Island Using Landsat Data: A Case Study of Metropolitan City Tehran (1988-2018). Sustainability 10, 4433. https://doi.org/10.3390/su10124433

Santos, A.R. dos, Oliveira, F.S. de, Silva, A.G. da, et al., 2017. Spatial and temporal distribution of urban heat islands. Sci. Total Environ. 605-606, 946-956. https://doi.org/10.1016/j.scitotenv.2017.05.275

Sarif, M.O., Jeganathan, C., Mondal, S., 2017. MODIS-VCF Based Forest Change Analysis in the State of Jharkhand. Proc. Natl. Acad. Sci. India Sect. A - Phys. Sci. 87, 751-767. https://doi.org/10.1007/s40010-017-0446-6

Sen, S., Roesler, J., Ruddell, B., Middel, A., 2019. Cool Pavement Strategies for Urban Heat Island Mitigation in Suburban Phoenix, Arizona. Sustainability 11, 4452. https://doi.org/10.3390/su11164452

Simwanda, M., Ranagalage, M., Estoque, R.C., Murayama, Y., 2019. Spatial Analysis of Surface Urban Heat Islands in Four Rapidly Growing African Cities. Remote Sens. 11, 1645. https://doi.org/10.3390/rs11141645

Singh, P., Kikon, N., Verma, P., 2017. Impact of land use change and urbanization on urban heat island in Lucknow city,
Central India: A remote sensing based estimate. Sustain. Cities Soc. 32, 100-114. https://doi.org/10.1016/j.scs.2017.02.018

Son, N.T., Chen, C.F., Chen, C.R., Thanh, B.X., Vuong, T.H., 2017. Assessment of urbanization and urban heat islands in Ho Chi Minh city, Vietnam using Landsat data. Sustain. Cities Soc. 30, 150-161. https://doi.org/10.1016/j.scs.2017.01.009

Sultana, S., Satyanarayana, A.N. V, 2018. Urban heat island intensity during winter over metropolitan cities of India using remote-sensing techniques: impact of urbanization. Int. J. Remote Sens. 1-39. https://doi.org/10.1080/01431161.2018.1466072

UN, 2016. The World's Cities in 2016. Departmentof Economic and Social Aff airs, Population Division (2016). The World's Cities in 2016 - Data Booklet (ST/ESA/ SER.A/392). https://doi.org/http://www.un.org/en/development/desa/populati on/publications/pdf/urbanization/the_worlds_cities_in_2016_da ta_booklet.pdf 